\title{
DNA Replication Damage
}

National Cancer Institute

\section{Source}

National Cancer Institute. DNA Replication Damage. NCI Thesaurus. Code C19348.

DNA sequence errors introduced via DNA replication. 